AL.2.2003-92

2

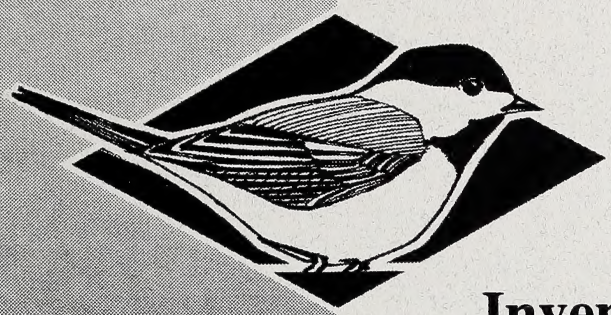

\title{
Inventory and Monitoring Protocol for Naturally Occurring Western Blue Flag \\ (Iris missouriensis) in Alberta
}

rish \& Widiffe Division

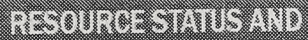

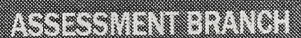

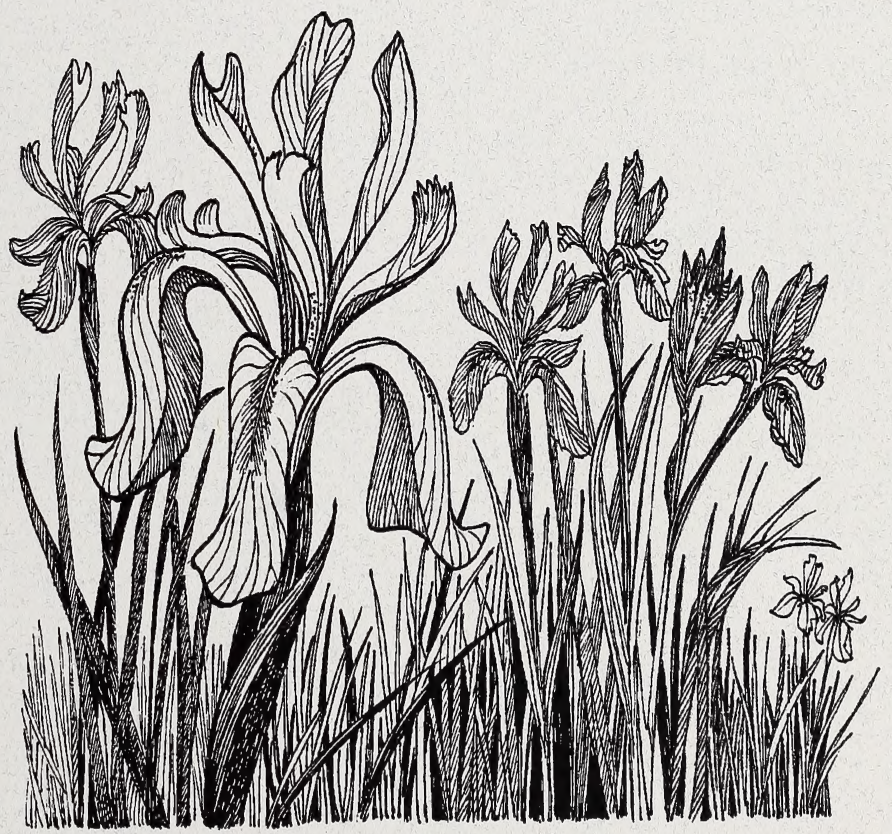

Alberta Species at Risk Report No. 66 



\title{
Inventory and Monitoring Protocol for Naturally Occurring Western Blue Flag (Iris missouriensis) in Alberta
}

\author{
Reg Ernst
}

Alberta Species at Risk Report No. 66

February 2003

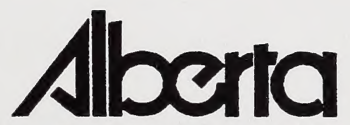

SUSTAINABLE RESOURCE DEVELOPMENT

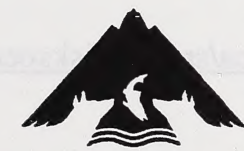

Alberta Conservation Association

Aunded by Albere Angles Hunters,
and other Conseverionises 
Publication No. I/099

ISBN: 0-7785-2811-1 (Printed Edition)

ISBN: 0-7785-2812-X (On-line Edition)

ISSN: 1496-7219 (Printed Edition)

ISSN: 1496-7146 (On-line Edition)

Illustration by: Brian Huffman

For copies of this report, contact:

Information Centre- Publications

Alberta Environment/ Alberta Sustainable Resource Development

Main Floor, Great West Life Building

9920- 108 Street

Edmonton, Alberta, Canada T5K 2M4

Telephone: (780) 422-2079

OR

Information Service

Alberta Environment/ Alberta Sustainable Resource Development \#100, 3115- 12 Street NE

Calgary, Alberta, Canada T2E 7J2

Telephone: (403) 297- 3362

OR

Visit our web site at:

http://www3.gov.ab.ca/srd/fw/riskspecies/

This publication may be cited as:

Ernst, R.D. 2003. Inventory and Monitoring Protocol for Naturally Occurring Western Blue Flag (Iris missouriensis) in Alberta. Alberta Sustainable Resource Development, Fish and Wildlife Division, Alberta Species at Risk Report No. 66. Edmonton, AB. 


\section{EXECUTIVE SUMMARY}

Following the release of the maintenance and recovery plan in 2002, several landowners advised of having western blue flag on their property. During the spring and summer of 2002 , an inventorying and monitoring program was developed and implemented.

Permission was requested and granted to inventory four of five newly discovered western blue flag sites, along with eleven previously known sites. Monitoring plots were set up at eleven of the sixteen known western blue flag locations in Alberta.

Western blue flag inventorying and monitoring protocol was developed based on the total number of stems at each site. Sites were designated according to size: small, medium, large, and extra large. Inventorying was a total site stem count, whereas monitoring was the sampling procedure developed to monitor site trend over time. Inventories for small and medium sites involved counting each individual stem over the entire site to attain the total site stem count. A grouping method was used to facilitate a total site stem count on large and extra large sites. Monitoring plots were established within selected sites to monitor site health and population trend over time. Site size and variability determined the number of monitoring plots for each site. Current site stem counts were compared with previous stem counts to determine overall health and population trend.

This project revealed a revised western blue flag population status of 59,200 stems at 15 of the 16 known locations; a dramatic increase from the previous population estimate of 14,757 stems. Although stem counts have risen dramatically, none of the new sites are located outside the previously known range of western blue flag. Nevertheless, a formal review of western blue flag status may be warranted based on its increased population. 


\section{ACKNOWLEDGEMENTS}

Funding for this project was provided through the Alberta Conservation Association and the Species at Risk Program of Alberta Fish and Wildlife Division. Thanks to those landowners that came forward to advise they had western blue flag on their property and to all the other landowners that provided access to their property. Jeff Bectell's help in locating new western blue flag sites was greatly appreciated. Thanks to Richard Quinlan and Kathryn Romanchuk for editing this report. 


\section{TABLE OF CONTENTS}

EXECUTIVE SUMMARY i

ACKNOWLEDGEMENTS ............................................................................................ ii

1.0 INTRODUCTION ...................................................................................................... 1

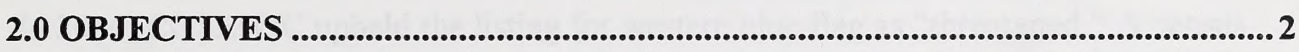

3.0 DISTRIBUTION AND GENERAL HABITAT ASSOCIATIONS .......................2

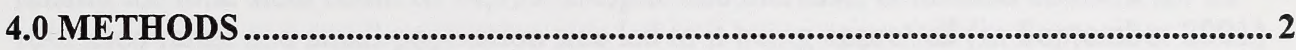

4.1 Public Awareness/Gaining Landowner Support ................................................................. 2

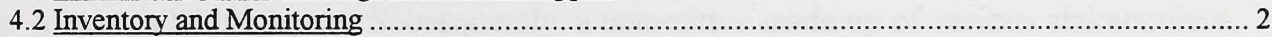

4.2.1 Inventory Procedure for Small and Medium Sites......................................................... 3

4.2.2 Inventory Procedure for Large and Extra Large Sites .................................................... 3

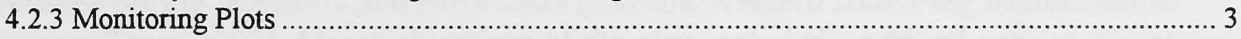

5.0 RESULTS .......................................................................................................... 4

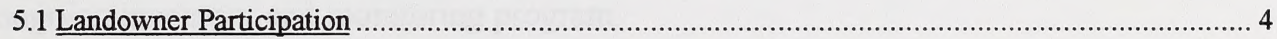

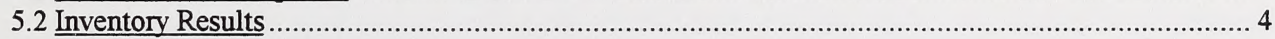

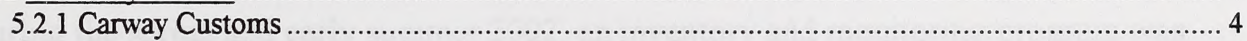

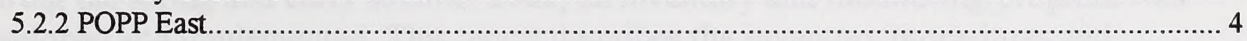

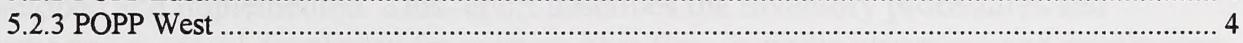

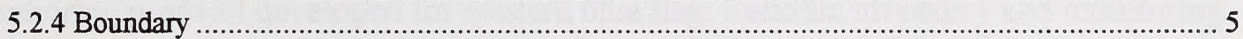

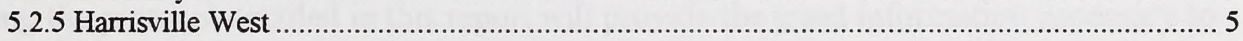

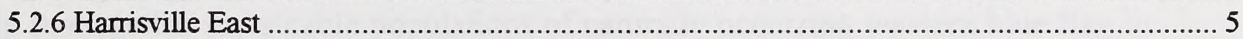

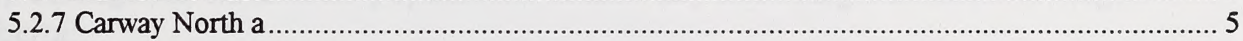

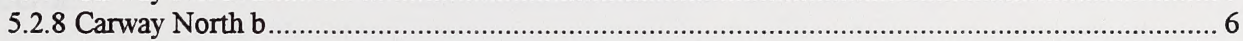

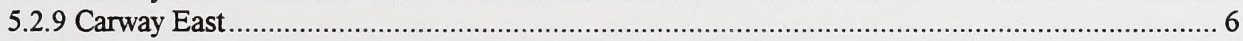

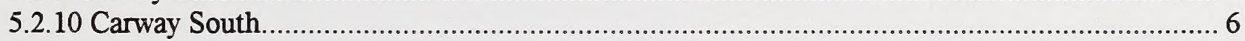

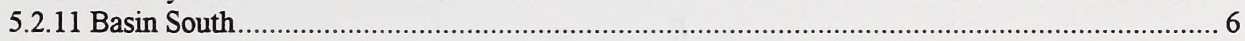

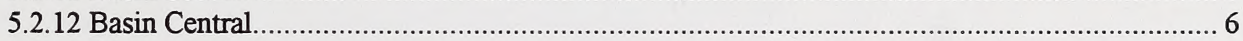

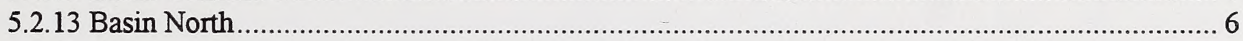

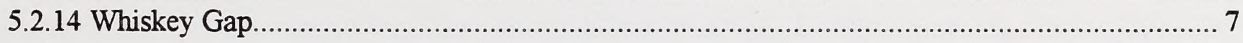

6.0 DISCUSSION $\ldots \ldots \ldots \ldots \ldots \ldots \ldots \ldots \ldots \ldots \ldots \ldots \ldots \ldots \ldots \ldots \ldots \ldots \ldots \ldots \ldots \ldots \ldots \ldots \ldots \ldots \ldots \ldots \ldots \ldots \ldots \ldots \ldots \ldots \ldots \ldots \ldots \ldots \ldots$

7.0 RECOMMENDATIONS ..................................................................................... 10

8.0 LITERATURE CITED $\ldots \ldots \ldots \ldots \ldots \ldots \ldots \ldots \ldots \ldots \ldots \ldots \ldots \ldots \ldots \ldots \ldots \ldots \ldots \ldots \ldots \ldots \ldots \ldots \ldots \ldots \ldots \ldots \ldots \ldots \ldots \ldots \ldots \ldots \ldots \ldots \ldots \ldots \ldots \ldots . . . . \ldots$

\section{LIST OF TABLES}

Table 1: Inventory information for all known naturally occurring western blue

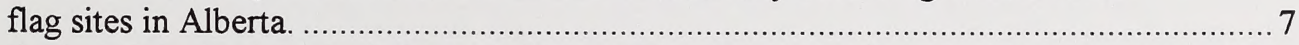

Table 2: Monitoring plot information from 11 western blue flag sites in Alberta. ........... 8 
Digitized by the Internet Archive in 2016 


\subsection{INTRODUCTION}

In Canada, naturally occurring western blue flag (Iris missouriensis) is known only from a small area of southwestern Alberta. Because of its restricted range and small population size, western blue flag was listed in 1990 as "threatened" by the Committee on the Status of Endangered Wildlife in Canada (COSEWIC). Up until 1999 there were only six occurrences known to exist, with a total population estimated at 7,500 stems (Gould 1999).

In 2000, COSEWIC upheld the listing for western blue flag as "threatened." A census was done based on known western blue flag locations, resulting in a revised population estimate of 9,275 stems (Ernst 2002). In 2001, a newly discovered site was inventoried raising the total stem count to 14,757 . Despite this increase, continued concern for its restricted range and small population size led to it being approved (in September 2001) by the Minister of Sustainable Resource Development for listing as a Threatened species in Alberta's Wildlife Act. Subsequently, a committee made up of various stakeholders, including area ranchers, was formed, and a maintenance and recovery plan was developed during late 2001 and early 2002 (Canada Western Blue Flag Maintenance/ Recovery Team 2002). Major objectives of the plan included a revised census of western blue flag based on information regarding new sites, and to develop and implement an ongoing inventory and monitoring program.

During the spring and early summer 2002, an inventory and monitoring program was developed and implemented. This report describes the inventory procedures and monitoring protocol developed for western blue flag. Periodic inventory and monitoring using the protocol detailed in this report will provide the trend information necessary to help manage for sustainable populations of naturally occurring western blue flag in Alberta. 


\subsection{OBJECTIVES}

The major objectives of the 2002 western blue flag inventory project were:

- Coordinate with landowners to investigate and inventory newly reported western blue flag sites.

口 Inventory all western blue flag sites with previous counts fewer than 500 stems.

- Develop and implement an ongoing inventory and monitoring program for western blue flag at all sites.

- Provide a revised population estimate of naturally occurring western blue flag in Alberta.

\subsection{DISTRIBUTION AND GENERAL HABITAT ASSOCIATIONS}

In Canada, naturally occurring western blue flag is limited to an area of less than $300 \mathrm{~km}^{2}$ in southwestern Alberta, and is restricted to the Foothills Grassland and Parkland subregions. Annual precipitation in these sub-regions ranges from 500 to $650 \mathrm{~mm}$, and the mean temperature for May to September is 11 to $13^{\circ} \mathrm{C}$ (summarized from Gould 1999). Soils are dark brown and black chernozems, with gleysols occurring on poorly drained sites.

Generally, western blue flag prefers sites where abundant spring and early summer moisture is present, but which dry out later in the season. It is normally found along ephemeral drainages and along the edge of moist depressions in association with a variety of species, most of which are characteristic of mesic (moist) or sub-hygric (wet for a significant portion of the growing season) conditions.

\subsection{METHODS}

\subsection{Public Awareness/Gaining Landowner Support}

An open house was held in Cardston on May 28, 2002 to inform the public about the recovery plan, and to increase awareness and gain landowner confidence. Copies of the western blue flag maintenance and recovery plan were widely distributed in the Cardston to Carway area. As an incentive to become involved in the process, ranchers were offered range management plans, and funding was provided for range improvements that would benefit western blue flag sites. Involvement in this cooperative process was voluntary.

\subsection{Inventory and Monitoring}

Western blue flag inventory and monitoring protocol was developed based on the total number of stems at each site. Site designations were based on size as follows: smallfewer than 500 stems, medium-501 to 2000 stems, large-2001 to 10,000 stems, and extra large- more than 10,001 stems. Generally, sites are considered separate if there is a different landowner involved, or if there is more than $500 \mathrm{~m}$ from the next nearest clump or stem. The two small sites at POPP (Police Outpost Provincial Park) were exceptions and treated separately because they were being managed differently (i.e. treatments being applied to one but not the other). For the purposes of this report, inventory is a total stem 
count (or census) at a site, and monitoring is the sampling procedure developed to monitor site trend over time.

\subsubsection{Inventory Procedure for Small and Medium Sites}

The site was initially surveyed by walking a series of transects; individual stems and clumps were then marked with flagging. After the entire site had been surveyed and marked, each individual stem was counted and the flagging was removed as counting proceeded. After all the stems had been counted, the site was re-surveyed and all of the flowering and fruiting stems were counted. The sum of stems plus fruiting/flowering stems represented the total stem count for that site. A hand-held tally counter was used to facilitate counting.

\subsubsection{Inventory Procedure for Large and Extra Large Sites}

It was highly impractical to count each individual stem on these sites due to the large number of stems involved, and because they were spread over a large area. Instead, a more practical grouping method was used to simplify counting. For large sites, a group of 10 western blue flag stems were clustered together to gain a visual picture of the area that that number of stems occupied. The site was then surveyed by walking a series of transects, and stems were counted based on using the grouping method. The same method was used for extra large sites, only the stem count was based on groups of 100 stems instead of 10 stems. A hand-held tally counter was used to facilitate counting.

\subsubsection{Monitoring Plots}

Monitoring plots were established to monitor the vigour of western blue flag over time. Indicators of western blue flag vigour included the following (Cook and Stubbendieck 1986):

1. Size and appearance of plants (withering, dead centres, plant senescence, clipped tops, and poor colour may be indicators of poor health).

2. Number of stems.

3. Number of flowering/fruiting stems.

4. Size or area of clump or site.

5. Associated plant species.

The number of monitoring plots for each site was selected by site size and variability, and were determined as follows: small sites-one for each 250 stems; medium sites-one for each 500 stems; large sites-one for each 1000 stems; and on extra large sites-one for each 2000 stems. Monitoring clumps were selected based on an assortment of clump sizes in a variety of different habitats. Where possible, discrete clumps were chosen to facilitate monitoring.

Monitoring plots were set up as follows: the selected clump was marked by four wooden stakes around the perimeter (one stake with the plot number on it), a GPS (Geographic Positioning System) position was recorded, and the plot was measured on two axes (N/S \& E/W). Total stems and flowering/fruiting stems were counted, site vigour was evaluated, associated species were noted, and a photo was taken of the plot (Appendix 1). 
The current site stem count will be compared with previous stem counts to determine overall health and population trend over time. Individual clump vigour is noted, but the critical factor is the overall site trend rather than trends within individual clumps (i.e. some clumps may die back and shrink while others may become more robust and grow).

\subsection{RESULTS}

\subsection{Landowner Participation}

In 2002, five additional landowners agreed to participate in the program to inventory and monitor western blue flag sites (10 landowners are now involved). The new sites are known as Carway Customs, Harrisville West, Basin South, Basin Central, and Basin North. Permission to inventory the Basin South site was not given, so the population estimate was based on an ocular examination.

\subsection{Inventory Results}

During June and July of 2002, an inventory of the new sites plus the Carway North b and Carway East sites increased the western blue flag total stem count by 43,689 . Four previously known sites (POPP East, POPP West, Carway South, and Whiskey Gap) were also inventoried. New site stem totals, as well as increases at previously inventoried sites, raised stem counts from 14,757 in 2001 (Ernst 2002) to 59,200 in 2002. All of the previously inventoried sites showed increases in 2002, likely because of an abundance of spring moisture.

See Table 1 for previous and current inventory information and Table 2 for monitoring plot information.

\subsubsection{Carway Customs}

This site was new for 2002 and consisted of two western blue flag clumps along drainages separated by about $100 \mathrm{~m}$. Monitoring plots were set up at each of the two clumps. The east clump had 102 stems with 3 flowering, and the west clump had 151 stems with 0 flowers. Total site stem count was 264 stems with 3 flowering. There may have been more flowering stems, but more than $90 \%$ of the stems in both clumps had been grazed down to about $50 \%$, which made an exact count difficult.

\subsubsection{POPP East}

This site is located in a transition zone from an ephemeral drainage to a well-drained rough fescue (Festuca scabrella)/shrubby cinquefoil (Potentilla fruticosa) community. Although it showed a modest increase in stem count $(+21)$, there was a decrease of 11 flowering stems. Conditions at this site may be suffering from smooth brome (Bromus inermis) invading and substantial litter build-up. Forty-one of the 198 stems on this site were growing under a dense willow (Salix spp.) canopy. Two monitoring plots were set up on this site; Plot 1: 60 stems, 11 flowering and Plot 2:16 stems, 2 flowering. This site is not grazed, and no treatments were applied to this property.

\subsubsection{POPP West}

This site is located close to the south shore of Police Outpost Lake along the willow edge. Much of the site remains saturated well into the summer, which may account for the 
steady decline in stem counts until the 2002 inventory (Table 1). Treatments to simulate livestock grazing (i.e. removing accumulated litter to allow for earlier soil warming and drying, and removing some of the competing vegetation) were applied during the autumn of 2000 , and the early spring and fall of 2002. Stem counts increased from 203 in 2001 to 458 in 2002, and flowering stems increased from 8 in 2001 to 70 in 2002. Two monitoring plots were set up at this site; Plot 1: 49 stems, 11 flowering and Plot 2: 36 stems, 5 flowering.

\subsubsection{Boundary}

This location is a large area spread over about $2 \mathrm{sq} . \mathrm{km}$ and contains 3 sites situated approximately 500 meters apart from each other. It was discovered in 2000, but permission to inventory was not obtained until 2001 . No monitoring plots were set up at this location in 2002 , however, because the landowner was unwilling to participate. The western blue flag on this property is considered adequately protected by an existing NCC (Nature Conservancy Canada) conservation easement.

The 2001 inventory results were 4996 stems, with 547 in flower or fruit (Table 1). Western blue flag habitat on two of the sites was in depressional areas, and on the third along a drainage. Generally, vigour on the site was good, but the proportion of flowering/fruiting stems was relatively low compared to some of the other sites.

\subsubsection{Harrisville West}

This site was new for 2002 and consisted of two patches of western blue flag about $50 \mathrm{~m}$ apart. One patch was in the ditch adjacent to a small drainage, and the other in a depression among willows. The patch in the willows may be relatively recent because of many small stems (juveniles) and only one flowering stem. Subsequent monitoring may indicate if that is the case. Some stems in the ditch had been dug out and removed. No grazing is done on this site. One monitoring plot was set up yielding 513 stems, 78 in fruit or flower. Total site stem count was 956 stems.

\subsubsection{Harrisville East}

This site was last inventoried in 2000 and contained 2,091 stems, 304 of which were in fruit or flower. Eight monitoring plots were set up in 2002. Most of the habitat for western blue flag on this site was along a gentle north-facing slope above the drainage, or on small knolls and terraces along the drainage. The site is relatively homogeneous. Total stem count for the monitoring plots was 356 stems, 46 in fruit or flower. This site is summer-grazed by cattle.

\subsubsection{Carway North a}

Last inventoried in 2000, this site had 6,049 stems, 256 in fruit or flower. 13 monitoring plots were set up in 2002. Western blue flag habitat on this site was variable, ranging from relatively well-drained sites along the edge of rough fescue/shrubby cinquefoil communities, to depressional areas in sedge (Carex sp.) communities, to dense understory in aspen (Populus tremuloides)/willow thickets. In recent years, much of the area was ungrazed; however, some haying has been done in one of the sedge meadows. Total stem count for 12 of the 13 monitoring plots was 821 . The number of stems in fruit or flower (from all 13 plots) was 105. 


\subsubsection{Carway North b}

This is a small site with western blue flag clumps scattered along a relatively steep southfacing slope, mostly in dense non-native grasses. A stem count estimate was done for this site in the late autumn of 2001 ( 300 stems), but the first true inventory was done during early summer of 2002. Total site stem count was 1033, with 134 in flower or fruit. Three monitoring plots were set up yielding 274 stems, 21 in flower or fruit. Some limited grazing occurs on this site.

\subsubsection{Carway East}

This is another site where a stem count estimate was done in 2001 ( 200 stems), but the actual inventory was done during early summer of 2002 . Western blue flag clumps on this site were scattered over a large area of about 200 ha. 3 monitoring plots were set up yielding 174 stems, 20 in fruit or flower. Total site stem count was 800 stems, 96 in flower or fruit. Portions of this site are impacted by grazing and haying.

\subsubsection{Carway South}

This is a small grazed site between a road and a water impoundment that showed a substantial increase in stem counts $(+346)$ for 2002 , but no difference in flowering stems since previously inventoried in 2000 . Habitat for western blue flag was mostly in welldrained areas adjacent to the water impoundment, but some stems occurred near the shore and twenty stems were in the ditch. Total site stem count was 916 , with 41 in flower or fruit. 4 monitoring plots were set up yielding 76 stems, 7 in flower or fruit.

\subsubsection{Basin South}

Permission to inventory this new site was not given in 2002, but an ocular examination of the site from the adjoining property indicated a large stand of western blue flag stems, estimated at more than 10,000 .

\subsubsection{Basin Central}

This new site for 2002 was relatively small in terms of area ( $5 \mathrm{ha})$, but large in terms of stem count, containing 11,149 stems, 2390 in flower or fruit (Table 1). 11 monitoring plots were set up yielding 1,268 stems, 144 in flower or fruit. Habitat for western blue flag was mainly in saturated meadows along drainage within a large basin. Spring rain and snow in 2002 resulted in substantial seepage into the basin causing very wet conditions. During winter and spring this site is used for grazing and calving. Vigour of western blue flag throughout this site was good, and there was a large proportion of flowering/fruiting stems.

\subsubsection{Basin North}

Also new for 2002, this is the largest western blue flag site known in Canada, containing 29,487 stems with 4473 in fruit or flower (Table 1). 15 monitoring plots were set up yielding 856 stems, 104 in fruit or flower. This site was somewhat unique because the majority of western blue flag was found on relatively well-drained upland sites on heavily grazed pasture; the balance found in wet meadows along the drainage. 


\subsubsection{Whiskey Gap}

This small upland site is somewhat unique because it is in the hills well above the valley floor. Most of the moisture it receives is likely from melting snowdrifts and rain. In 2002, stem counts were up by 52 (total of 233) and flowering stems were up by 8 (10 total). No monitoring plots were set up at this site because there were no suitable western blue flag clumps; plants occurred as individuals or in very small groups.

Table 1: Inventory information for all known naturally occurring western blue flag sites in Alberta.

\begin{tabular}{|c|c|c|c|}
\hline Site & Date & $\begin{array}{l}\text { Total } \\
\text { Stems }\end{array}$ & $\begin{array}{c}\text { \# of } \\
\text { Fruits/Flowers }\end{array}$ \\
\hline $\begin{array}{l}\text { **Carway } \\
\text { Customs }\end{array}$ & $11 / 07 / 02$ & 264 & 3 \\
\hline \multirow[t]{3}{*}{ POPP East } & $27 / 06 / 00$ & 175 & 14 \\
\hline & $04 / 07 / 01$ & 177 & 26 \\
\hline & $27 / 06 / 02$ & 198 & 15 \\
\hline \multirow[t]{5}{*}{ POPP West } & 1989 & 650 & 6 \\
\hline & 1998 & 325 & 1 \\
\hline & $27 / 06 / 00$ & 219 & 14 \\
\hline & $04 / 07 / 01$ & 203 & 8 \\
\hline & $27 / 06 / 02$ & 458 & 70 \\
\hline $\begin{array}{l}\text { Boundary } \\
\text { (3 sites) }\end{array}$ & $02 / 07 / 01$ & 4996 & 547 \\
\hline $\begin{array}{l}* * \text { Harrisville } \\
\text { West }\end{array}$ & $11 / 07 / 02$ & 956 & N/a \\
\hline \multirow{3}{*}{$\begin{array}{c}\text { Harrisville } \\
\text { East }\end{array}$} & 1989 & 1500 & $\mathrm{~N} / \mathrm{a}$ \\
\hline & $03 / 07 / 00$ & 2091 & 304 \\
\hline & $30 / 06 / 02$ & N/a & $\mathrm{N} / \mathrm{a}$ \\
\hline \multirow{3}{*}{$\begin{array}{l}\text { Carway } \\
\text { North a }\end{array}$} & 1989 & 5000 & $\mathrm{~N} / \mathrm{a}$ \\
\hline & $05 / 07 / 00$ & 6049 & 256 \\
\hline & $16 / 07 / 02$ & N/a & N/a \\
\hline $\begin{array}{l}\text { * Carway } \\
\text { North b }\end{array}$ & $15 / 07 / 02$ & 1033 & 134 \\
\hline $\begin{array}{l}\text { * Carway } \\
\text { East }\end{array}$ & $15 / 07 / 02$ & 800 & 134 \\
\hline \multirow{2}{*}{$\begin{array}{l}\text { Carway } \\
\text { South }\end{array}$} & $06 / 07 / 00$ & 570 & 42 \\
\hline & $05 / 07 / 02$ & 916 & 41 \\
\hline $\begin{array}{l}* * * \text { Basin } \\
\text { South }\end{array}$ & $09 / 07 / 02$ & $>10,000$ & $\mathrm{~N} / \mathrm{a}$ \\
\hline $\begin{array}{c}* * \text { Basin } \\
\text { Central }\end{array}$ & $09 / 07 / 02$ & 11,149 & 2390 \\
\hline $\begin{array}{l}* * \text { Basin } \\
\text { North }\end{array}$ & $10 / 07 / 02$ & 29,487 & 4473 \\
\hline \multirow[t]{4}{*}{ Whiskey Gap } & 1989 & 203 & 0 \\
\hline & 1998 & 111 & 2 \\
\hline & $27 / 06 / 00$ & 171 & 2 \\
\hline & $27 / 06 / 02$ & 233 & 10 \\
\hline
\end{tabular}

* Estimate done in 2001, first inventoried in 2002

** New site, first inventoried in 2002

*** New site, not inventoried (based on ocular estimate)

N/a - Information not available (no previous inventory, or data not collected ) 
Total Stem Count Estimates:

1989 Western blue flag population estimate $=7500$ stems

2000 Western blue flag population estimate $=9275$ stems

2001 Western blue flag population estimate $=14,757$ stems

2002 Western blue flag population estimate $=59,200$ stems

(does not include estimate from Basin South)

Table 2: Monitoring plot information from 11 western blue flag sites in Alberta.

\begin{tabular}{|c|c|c|c|c|}
\hline Site & Date & $\begin{array}{c}\text { \# of } \\
\text { Plots }\end{array}$ & \# Stems & \# Fruits/Flowers \\
\hline $\begin{array}{c}\text { Carway } \\
\text { Customs }\end{array}$ & $11 / 07 / 02$ & 2 & 253 & 3 \\
\hline $\begin{array}{c}\text { POPP } \\
\text { East }\end{array}$ & $27 / 06 / 02$ & 2 & 76 & 13 \\
\hline $\begin{array}{c}\text { POPP } \\
\text { West }\end{array}$ & $27 / 06 / 02$ & 2 & 85 & 16 \\
\hline $\begin{array}{c}\text { Harrisville } \\
\text { West }\end{array}$ & $11 / 07 / 02$ & 1 & 513 & 78 \\
\hline $\begin{array}{c}\text { Harrisville } \\
\text { East }\end{array}$ & $30 / 06 / 02$ & 8 & 356 & 46 \\
\hline $\begin{array}{c}\text { Carway } \\
\text { North a }\end{array}$ & $16 / 07 / 02$ & 13 & 821 & 105 \\
\hline $\begin{array}{c}\text { Carway } \\
\text { North b }\end{array}$ & $15 / 07 / 02$ & 3 & 274 & 21 \\
\hline $\begin{array}{c}\text { Carway } \\
\text { East }\end{array}$ & $15 / 07 / 02$ & 3 & 174 & 70 \\
\hline $\begin{array}{c}\text { Carway } \\
\text { South }\end{array}$ & $05 / 07 / 02$ & 4 & 76 & 144 \\
\hline $\begin{array}{c}\text { Basin } \\
\text { Central }\end{array}$ & $09 / 07 / 02$ & 11 & 1268 & 104 \\
\hline $\begin{array}{c}\text { Basin } \\
\text { North }\end{array}$ & $10 / 07 / 02$ & 15 & 856 & 7 \\
\hline
\end{tabular}

\subsection{DISCUSSION}

Naturally occurring western blue flag sites in Alberta are highly variable in size and plant density; the smallest has fewer than 300 stems spread over less than 100 square meters, and the largest has about 30,000 stems spread over several hectares. On the smaller sites, limited area and low plant density make them particularly vulnerable to disturbance and fluctuating environmental conditions; therefore, counting all of the stems (an inventory) is necessary (and feasible) for effective monitoring. Conversely, the high density of stems on large and extra large sites makes setting up monitoring plots within selected clumps the most practical and effective method of monitoring site health and population trend over time.

Previous reports on western blue flag indicated that it was vulnerable to heavy grazing (reviewed in Gould 1999). This may be true on sites where marginal habitat conditions exist, but on sites where seemingly optimum conditions exist, it appears to be tolerant of heavy grazing (Eckert et al. 1973, California Department of Food and Agriculture [CDFA] 2002). This is true of the Basin sites, where evidence such as clump 
pedestalling, trampling, hoof punctures, and weedy species indicate that heavy grazing has occurred for some time. It appears that heavy use on most of the Basin sites has removed the majority of the competing vegetation, allowing western blue flag to increase.

Optimum habitat conditions for western blue flag in Alberta have not been studied, but perhaps examining the Basin sites, where the largest known sites of western blue flag in Canada have been found, will provide some clues. The Basin sites are located in a deep, wide, north/south oriented basin protected from winds, that receives ample spring and early summer moisture seeping in from the surrounding slopes. Soils on the Basin sites are likely gleysols, soils characteristic of poorly drained areas, and plant associations are mainly sedges, again characteristic of poorly drained sites. All three Basin sites received substantial early season rain and snow in 2002, and western blue flag populations were extremely high at all locations. Additionally, the Basin Central and Basin North sites were heavily grazed, yet vigour of western blue flag was good at both sites and it did not appear to be suffering from the intensive use. In time, the monitoring plots set up in 2002 may reveal additional information on conditions favourable, or unfavourable, to western blue flag.

Recent studies, including this one, indicate that western blue flag tolerates a wider range of ecological and management conditions than previously thought (Ernst 2002). In this project, western blue flag was found in a variety of habitats, ranging from relatively dry uplands, to mesic sites along ephemeral drainages, to depressional areas, and in the understory of aspen groves. Early reports indicated that western blue flag had a strong association with willow, but in this study that correlation was weak or non-existent. Willow was not present at many of the western blue flag sites.

Associated plant species varied from typical native grasses, sedges, and forbs, to introduced grasses such as bluegrass (Poa spp.), Timothy (Phleum pratense), and brome, and invasive weeds such as Canada thistle (Cirsium arvense). On some sub-sites, western blue flag displayed a high degree of competitiveness with non-native species, but it is not known how long the invasive species have been present, or if western blue flag can endure these conditions over time.

Western blue flag is considered unpalatable to livestock. Generally, observations at the Alberta sites supported this assumption, however, at the Carway Customs site, the only two clumps known to exist there were heavily grazed during the spring of 2002. This was puzzling considering there was adequate palatable forage around the western blue flag plants. Two calves died in this pasture during the early summer of 2002. There is no specific reason to link their deaths to the grazed western blue flag, but the observation is noted in case a pattern develops at this location. Even if their deaths were related to poisoning, there are other poisonous plants on these rangelands besides western blue flag such as hemlock (Cicuta spp.) and larkspur (Delphinium spp.). Western blue flag is considered toxic to livestock (reviewed in Gould 1999, Whitson et al.1996, CDFA 2002), but several range managers in the U.S. were contacted and no reports were received of any known livestock fatalities from grazing western blue flag. 
Abundant spring rain and snow in 2002 may account for the increased stem counts at nearly all of the previously inventoried western blue flag sites, however, continued monitoring would be necessary to rule out any other factors that may have contributed to the increase. For example, recruitment at the Carway South site appeared to be very high in 2002 , but it cannot be certain whether that was due to the abundant spring moisture, or because the construction of a pond and lowering of the water table in recent years may have set back the western blue flag population and it is just now recovering. The increased site stem count at Whiskey Gap may be attributed, in part, to cattle being excluded from the site in spring 2002 , in addition to the unusually wet spring conditions. In response to declining stem counts, treatments to simulate livestock grazing were applied to the POPP West site in 2000 and 2002. Inventory results for 2002 indicated an increase of 255 stems from the previous year. Annual monitoring is recommended for this site, and should indicate if the dramatic increase in vigour is a result of the treatments, or a combination of the treatments and some other factor(s).

The POPP East site, which showed a modest increase in stem count, but a decrease in flowering stems, may be suffering from the invasion of smooth brome (Bromus inermis) and substantial litter build-up. Conditions at this site might be improved by control of invading species and by removing some of the accumulated litter. At the Carway North a site, it was noted that litter accumulation could become a problem if current management practices continue.

This project revealed a revised western blue flag population status of 59,200 stems at 15 of 16 known locations; a dramatic increase from the previous population estimate of 14,757 stems. Although stem counts have risen dramatically, none of the new sites are located outside the previously known range of western blue flag. Nevertheless, a formal review of western blue flag status may be warranted based on the substantial increase in its population.

\subsection{RECOMMENDATIONS}

- The maintenance and recovery plan calls for a formal review of western blue flag status if landowners report numerous additional sites. All of the new sites inventoried in 2002 are within its original range; however, the population has increased fourfold following the inventories completed in 2002. A review of western blue flag status is warranted based on the substantial increase in the population.

- The Whiskey Gap and POPP sites should be inventoried annually. The plots established at all other sites should be monitored annually; if site trend is down by more than $10 \%$ from the count done in 2002 , a total stem count should be done.

- Continue to search for new sites with the cooperation of landowners, and continue the cooperative approach with landowners to conserve western blue flag sites. 
- On sites where western blue flag has been grazed and there are livestock fatalities, do a necropsy on the carcasses to determine if there is any link between the livestock deaths and the grazing on western blue flag. 


\subsection{LITERATURE CITED}

Canada Western Blue Flag Maintenance/Recovery Team. 2002. Maintenance and Recovery Plan for Western Blue Flag (Iris missouriensis) in Canada. Alberta Sustainable Resource Development, Fish and Wildlife Division, Alberta Species at Risk Recovery Plan No.1, Edmonton, AB. 18 pp.

Cook, C. W. and J. Stubbendieck, (eds). 1986. Range Research: Basic Problems and Techniques. Society for Range Management, Denver, CO. pp 64-66.

Eckert, R. E., Jr., A. D. Bruner, G. J. Klomp, and F. F. Peterson. 1973. Control of rocky mountain iris and vegetation response on mountain meadows. J. Range Management 26(5): 352-355.

Ernst, R. 2002. A census and recommendations for management for western blue flag (Iris missouriensis) in Alberta. Alberta Sustainable Resource Development, Fish and Wildlife Division, Alberta Species at Risk Report No. 38. Edmonton, AB.

Gould, J. 1999. Status of the Western blue flag (Iris missouriensis) in Alberta. Alberta Environmental Protection, Fisheries and Wildlife Management Division, and Alberta Conservation Association, Wildlife Status Report No. 21. Edmonton, AB. 22 pp.

California Department of Food and Agriculture (CDFA). 2002. Encycloweedia: Notes on Identification, Biology, and Management of Plants Defined as Noxious Weeds by California Law. [Online] http://pi.cdfa.ca.gov/weedInfo/IRIS2.html. Accessed 01 August 2002.

Whitson, T. D., editor. 1996. Weeds of the West. Pioneer of Jackson Hole. Jackson, Wyoming. p. 355. 


\section{List of Titles in This Series \\ (as of January 2003)}

No. 1 Alberta species at risk program and projects 2000-2001, by Alberta Sustainable Resource Development, Fish and Wildlife Division. (2001)

No. 2 Survey of the peregrine falcon (Falco peregrinus anatum) in Alberta, by R. Corrigan. (2001)

No. 3 Distribution and relative abundance of the shortjaw cisco (Coregonus zenithicus) in Alberta, by M. Steinhilber and L. Rhude. (2001)

No. 4 Survey of the bats of central and northwestern Alberta, by M.J. Vonhof and D. Hobson. (2001)

No. 52000 survey of the Trumpeter Swan (Cygnus buccinator) in Alberta, by M.L. James and A. James. (2001)

No. 6 2000/2001 Brassy Minnow inventory at Musreau Lake and outlet, by T. Ripley. (2001)

No. 7 Colonial nesting waterbird survey in the Northwest Boreal Region - 2000, by M. Hanneman and M. Heckbert. (2001)

No. 8 Burrowing owl trend block survey and monitoring - Brooks and Hanna areas, by D. Scobie and R. Russell. (2000)

No. 9 Survey of the Lake Sturgeon (Acipenser fulvescens) fishery on the South Saskatchewan River, Alberta (June-September, 2000), by L.A. Winkel. (2000)

No. 10 An evaluation of grizzly bear-human conflict in the Northwest Boreal Region of Alberta (19912000) and potential mitigation, by T. Augustyn. (2001)

No. 11 Harlequin duck monitoring in the Northern East Slopes of Alberta: 1998-2000 preliminary results, by J. Kneteman and A. Hubbs. (2000)

No. 12 Distribution of selected small mammals in Alberta, by L. Engley and M. Norton. (2001)

No. 13 Northern leopard frog reintroduction. Raven River - Year 2 (2000), by K. Kendell. (2001)

No. 14 Cumulative effects of watershed disturbances on fish communities in the Kakwa and Simonette watersheds. The Northern Watershed Project. Study 3 Progress report, by T. Thera and A. Wildeman. (2001)

No. 15 Harlequin duck research in Kananaskis Country in 2000, by C.M. Smith. (2001)

No. 16 Proposed monitoring plan for harlequin ducks in the Bow Region of Alberta, by C.M. Smith. (2001)

No. 17 Distribution and relative abundance of small mammals of the western plains of Alberta as determined from great horned owl pellets, by D. Schowalter. (2001)

No. 18 Western blue flag (Iris missouriensis) in Alberta: a census of naturally occurring populations for 2000 , by R. Emst. (2000)

No. 19 Assessing chick survival of sage grouse in Canada, by C.L. Aldridge. (2000)

No. 20 Harlequin duck surveys of the Oldman River Basin in 2000 , by D. Paton. (2000) 
No. 21 Proposed protocols for inventories of rare plants of the Grassland Natural Region, by C. Wallis. (2001)

No. 22 Utilization of airphoto interpretation to locate prairie rattlesnake (Crotalus viridis viridis) hibernacula in the South Saskatchewan River valley, by J. Nicholson and S. Rose. (2001)

No. 23 2000/2001 Progress report on caribou research in west central Alberta, by T. Szkorupa. (2001)

No. 24 Census of swift fox (Vulpes velox) in Canada and Northern Montana: 2000-2001, by A. Moehrenschlager and C. Moehrenschlager. (2001)

No. 25 Population estimate and habitat associations of the long-billed curlew in Alberta, by E.J. Saunders. (2001)

No. 26 Aerial reconnaissance for piping plover habitat in east-central Alberta, May 2001, by D.R.C. Prescott. (2001)

No. 27 The 2001 international piping plover census in Alberta, by D.R.C. Prescott. (2001)

No. 28 Prairie rattlesnake (Crotalus viridis viridis) monitoring in Alberta - preliminary investigations (2000), by S.L. Rose. (2001)

No. 29 A survey of short-horned lizard (Phrynosoma hernandesi hernandesi) populations in Alberta, by J. James. (2001)

No. 30 Red-sided garter snake (Thamnophis sirtalis parietalis) education and relocation project - final report, by L. Takats. (2002)

No. 31 Alberta furbearer harvest data analysis, by K.G. Poole and G. Mowat. (2001)

No. 32 Measuring wolverine distribution and abundance in Alberta, by G. Mowat. (2001)

No. 33 Woodland caribou (Rangifer tarandus caribou) habitat classification in northeastern Alberta using remote sensing, by G.A. Sanchez-Azofeifa and R. Bechtel. (2001)

No. 34 Peregrine falcon surveys and monitoring in the Parkland Region of Alberta, 2001, by R. Corrigan. (2002)

No. 35 Protocol for monitoring long-toed salamander (Ambystoma macrodactylum) populations in Alberta, by T. Pretzlaw, M. Huynh, L. Takats and L. Wilkinson. (2002)

No. 36 Long-toed salamander (Ambystoma macrodactylum) monitoring study in Alberta: summary report 1998-2001, by M. Huynh, L. Takats and L. Wilkinson. (2002)

No. 37 Mountain plover habitat and population surveys in Alberta, 2001, by C. Wershler and C. Wallis. (2002)

No. 38 A census and recommendations for management for western blue flag (Iris missouriensis) in Alberta, by R. Ernst. (2002)

No. 39 Columbian mountain amphibian surveys, 2001, by D. Paton. (2002)

No. 40 Management and recovery strategies for the Lethbridge population of the prairie rattlesnake, by $R$. Ernst. (2002) 
No. 41 Western (Aechmophorus occidentalis) and eared (Podiceps nigricollis) grebes of central Alberta: inventory, survey techniques and management concerns, by S. Hanus, $\mathrm{H}$. Wollis and $\mathrm{L}$. Wilkinson. (2002)

No. 42 Northern leopard frog reintroduction - year 3 (2001), by K. Kendell. (2002)

No. 43 Survey protocol for the northern leopard frog, by K. Kendell. (2002)

No. 44 Alberta inventory for the northern leopard frog (2000-2001), by K. Kendell. (2002)

No. 45 Fish species at risk in the Milk and St. Mary drainages, by RL\&L Environmental Services Ltd. (2002)

No. 46 Survey of the loggerhead shrike in the southern aspen parkland region, 2000-2001, by H. Kiliaan and D.R.C. Prescott. (2002)

No. 47 Survey of native grassland butterflies in the Peace parkland region of northwestern Alberta - 2001, by M. Hervieux. (2002)

No. 48 Caribou range recovery in Alberta: 2001/02 pilot year, by T. Szkorupa. (2002)

No. 49 Peace parkland native grassland stewardship program 2001/02, by A. Baker. (2002)

No. 50 Carnivores and corridors in the Crowsnest Pass, by C. Chetkiewicz. (2002)

No. 512001 Burrowing owl trend block survey and monitoring, Brooks and Hanna areas, by D. Scobie. (2002)

No. 52 An evaluation of the ferruginous hawk population in Alberta based on recent trend data, by D.P. Stepnisky, G.L. Erickson, J. Iwaasa and B. Taylor. (2002)

No. 53 Alberta amphibian call surveys. A pilot year. Final report, by L. Takats and C. Priestley. (2002)

No. 54 Utilization of a roadside survey technique to survey burrowing owl (Athene cunicularia hypugaea) in southeastern Alberta, by J. Nicholson and C. Skiftun. (2002)

No. 55 Alberta species at risk program and projects 2001-2002, by Alberta Sustainable Resource Development, Fish and Wildlife Division. (2002)

No. 56 Developing a habitat-based population viability model for greater sage-grouse in southeastern Alberta, by C.L. Aldridge. (2001)

No. 57 Peregrine falcon surveys and monitoring in the Northeast Boreal Region of Alberta, 2001, by R. Corrigan. (2002)

No. 582002 burrowing owl trend block survey and monitoring, Brooks area, by R.F. Russell. (2002)

No. 59 Rare plant inventory of the eastern edge of the lower foothills natural subregion, west-central Alberta, by J. Doubt. (2002)

No. 60 Western (Aechmophorus occidentalis) and eared (Podiceps nigricollis) grebes of central Alberta: 2002 field summary, by S. Hanus, H. Wollis and L. Wilkinson. (2002)

No. 61 Inventory of western spiderwort (Tradescantia occidentalis) in Alberta: 2002, by S. Peters. (2003) 
No. 62 Bullsnakes (Pituophis catenifer sayi) in Alberta: literature review and data compilation, by K. J. Kissner and J. Nicholson. (2003) 
1. 

National Library of Canada
Bibliotheqque nationale

eque nationale du Canada

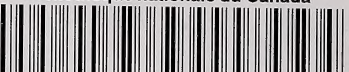

33286525455669 